\title{
In Vitro Synthesis of Oxalic Acid Has No Relevant Influence on Plasma Oxalic Acid Levels in Haemodialysis Patients
}

\author{
By P. Balcke, P. Schmidt, J. Zazgornik, A. Haubenstock and H. Kopsa \\ I. Medizinische Universitätsklinik (Vorstand: Prof. Dr. Dr. h.c. E. Deutsch) Wien
}

(Received July 27/November 23, 1983/January 6, 1984)

\begin{abstract}
Summary: Plasma oxalic acid concentrations were measured in 13 chronic haemodialysis patients. The mean plasma oxalic acid concentration was $128.0 \pm 48.6 \mu \mathrm{mol} / 1$, being approximately 8 times higher than the plasma concentration of 14 volunteers $(\overline{\mathrm{x}}=16.8 \pm 5.2 \mu \mathrm{mol} / \mathrm{l})$. Ultrafiltrates obtained in vivo from these patients showed a mean oxalic acid concentration of $138.2 \pm 56.5 \mu \mathrm{mol} / \mathrm{l}$. Since in vivo ultrafiltrates are free of erythrocytes and plasma enzymes, an in vitro synthesis of oxalic acid from precursors by erythrocytes and plasma enzymes can be excluded. As the oxalic acid concentration of plasma corresponded to that of in vivo ultrafiltrates, it is concluded that any in vitro formation of oxalic acid in haemodialysis patients must be negligibly small, and is irrelevant for the measurement of plasma oxalic acid levels in patients receiving regular haemodialysis.
\end{abstract}

\section{In vitro-Synthese von Oxalsäure ist ohne Bedeutung für die Bestimmung von Oxalsäure im Plasma bei Hämodialysepatienten}

Zusammenfassung: Bei 13 chronischen Hämodialysepatienten wurde die Konzentration von Oxalsäure im Plasma bestimmt. Die mittlere Oxalsäurekonzentration im Plasma lag bei 128,0 $\pm 48,6 \mu \mathrm{mol} / \mathrm{l}$ und war damit etwa $8 \mathrm{mal}$ höher als der Wert, der bei 14 Referenzpersonen gemessen wurde $(\overline{\mathrm{x}}=16,8 \pm 5,2 \mu \mathrm{mol} / \mathrm{l})$. Ultrafiltrate, die in vivo von diesen Dialysepatienten gewonnen worden waren, wiesen eine mittlere Oxalsäurekonzentration von $138,2 \pm 56,5 \mu \mathrm{mol} / \mathrm{A}$ auf. $\mathrm{Da}$ in in vivo-Ultrafiltraten Erythrocyten und Plasmaenzyme nicht enthalten sind, kann eine in vitro-Synthese von Oxalsäure durch Erythrocyten und Plasmaenzyme aus Vorstufen ausgeschlossen werden. Durch den Nachweis annähernd gleich hoher Oxalsäurekonzentrationen in Plasma und Ultrafiltraten kann angenommen werden, daß eine in vitro-Synthese von Oxalsäure bei Hämodialysepatienten vernạchlässigbar klein und unbedeutend für die Bestimmung der Konzentration von Oxalsạure im Plasma bei Diạlysepatienten ist.

\section{Introduction}

Increased plasma oxalic acid concentrations have been described in patients undergoing chronic hạemodialysis $(1,2,3)$. However the normal range of plasma oxalic acid is still a matter of dispute. Using chemical, fluorometric or enzymic methods the nor= mal range of plasma oxalic acid is about $10-20$ $\mu \mathrm{mol} / \mathrm{l}$, being approximately 10 times higher than the concentration obtained by human in vivo isotopic investigations (range of plasma oxalic acid 1-3 $\mu \mathrm{mol} / 1$ (4-7)). This discrepancy was recently re- solved by $A$ kcay \& Rose, who demonstrated that oxalic acid is synthesized from precursors in vitro by erythrocytes when samples are allowed to stand, thus resulting in erroneously high plasma levels in normals (8). An accumulation in the plasma of precursors of oxalic acid can be expected in uraemia. The question therefore arises of whether the increased values found in haemodialysis are due to a genuine physiological increase of oxalic acid, or to an increased conversion of accumulated precursors by erythrocytes and plasma enzymes in vitro. Ultrafil- 
tration before the haemodialysis, using dialysis machines adapted for ultrafiltration, offers the opportunity to obtain ultrafiltrates free of erythrocytes and enzymes in vivo. Oxalic acid has a low molecular weight $\left(M_{\mathrm{r}}=90\right)$ and shows negligible protein binding; it therefore passes freely across the dialysis membrane, so that its concentration in the ultrafiltrate reflects its plasma level. In the present study oxalic acid concentrations were compared in in-vivo ultrafiltrates and in contemporaneous plasma samples of 13 patients undergoing chronic haemodialysis.

\section{Materials and Methods}

Ultrafiltrates were obtained in vivo from 13 chronic haemodialysis patients by 10 minutes ultrafiltration before the beginning of the haemodialysis session, as described by Schmidt and coworkers (9). No patient suffered from primary hyperoxalaemia. Capillary kidneys (ASAHI AM 20) were used for ultrafiltration. The transmembrane pressure was $300 \mathrm{~mm} \mathrm{Hg}$. Blood samples were drawn simultaneously and centrifuged within 1 hour (fig. 1). Former studies showed that ultrafiltrate concentrations of low molecular weight substances like creatinine and potassium correspond to plasma levels after 10 minutes ultrafiltration (creatinine $r=0.88$, potassium $r=0.92)(9)$. The behaviour of oxalic acid can be expected to be similar to that of creatinine as the molecular weights of these two substances differ only moderately $\left(M_{\mathrm{r}}\right.$ creatinine 113 , oxalic acid 90 ) and since protein binding of oxalic acid is minimal.

Oxalic acid determinations were performed according to the photometric method described by Krugers Dagneaux et al. (4). Since plasma proteins can influence the accuracy of the oxalic acid determination, ultrafiltrates of the plasma samples were used. Ultrafiltration of diluted plasma samples $(1: 10)$ was performed using Amicon Filters Diaflo PM 10 with pore sizes corresponding to 10000 Dalton.

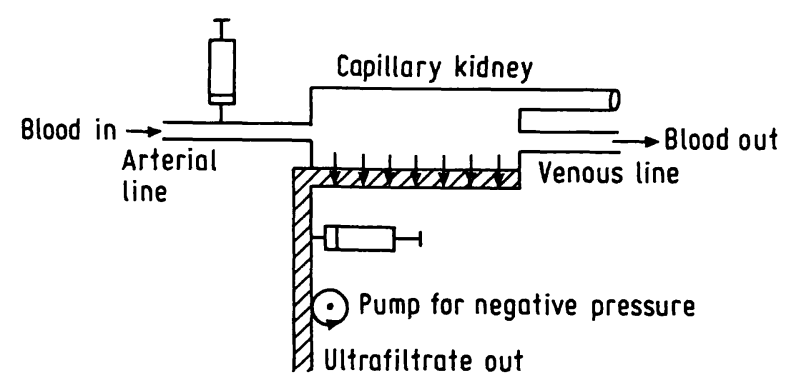

Fig. 1. Model of ultrafiltration procedure in vivo.

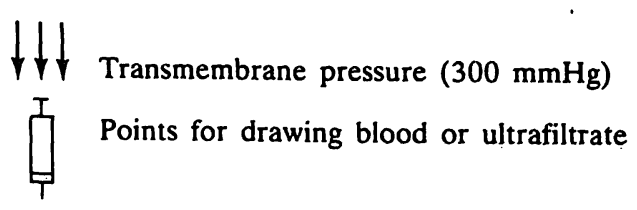

Ultrafiltrates obtained in this way and in-vivo ultrafiltrates were used for oxalic acid determination.

Since protein binding of oxalic acid is minimal, concentrations in in-vivo and in-vitro ultrafiltrates can be assumed to be equal to plasma levels.

\section{Results}

The mean plasma oxalic acid concentration of the 13 chronic haemodialysis patients under investigation was $128.0 \pm 48.6 \mu \mathrm{mol} / 1$, being approximately 8 times higher than the mean plasma oxalic acid level of 14 normal volunteers $(\bar{x}=16.8 \pm 5.2 \mu \mathrm{mol} / \mathrm{l})$. The mean oxalic acid level in the in-vivo ultrafiltrates of these patients was $138.2 \pm 56.5 \mu \mathrm{mol} / \mathrm{l}$. Thus plasma oxalic acid concentrations were 8.7 per cent lower than the mean oxalic acid concentration . measured in the in-vivo ultrafiltrates (Student's t-test for paired samples: $t=2.26, p<0.05$ ). The lower mean oxalic acid level in plasma compared with that of the in-vivo ultrafiltrates is probably due to small losses of oxalic acid during the plasma determination procedure. The correlation between the oxalic acid levels in plasma and in the in-vivo ultrafiltrates was highly significant $(r=0.96, p<0.001)$ (fig. 2$)$.

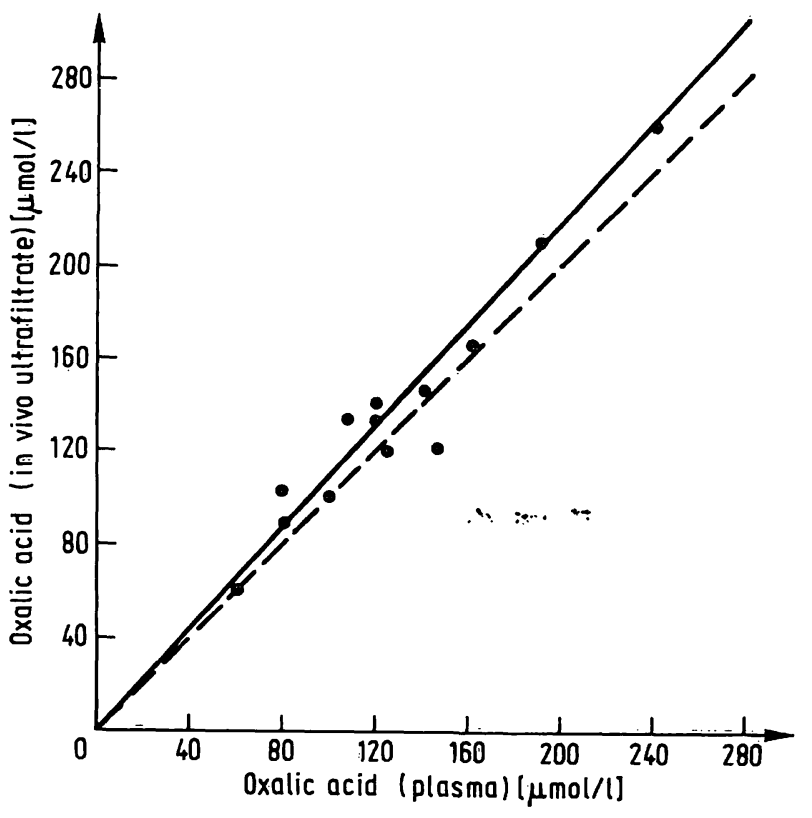

Fig. 2. Correlation between oxalic acid concentration in plasma and in-vivo ultrafiltrates.

- Regression line

- - Ideal regression line

\section{Discussion}

The mean plasma oxalic acid concentration in chronic haemodialysis patients was about 8 times higher than that in normal volunteers. The mean oxalic acid level in plasma was not higher than the mean oxalic acid .concentration of in-vivo ultrafiltrates. Furthermore oxalic acid concentrations in plasma and in plasma ultrafiltrates showed a highly significant cor- 
relation. Since an in vitro synthesis of oxalic acid can be excluded in in-vivo ultrafiltrate, we assume that spontaneous generation of oxalic acid in blood samples is of negligible significance in the determination of plasma oxalic acid levels in uraemic patients.

However, our results do not necessarily disprove the relevance of in vitro synthesis of oxalic acid for the measurement of plasma oxalic acid concentrations in normals. It was suggested that the estimated normal range for plasma oxalic acid is erroneously high, owing to the in vitro conversion of glyoxylic acid (a precursor) to oxalic acid by erythrocytes in blood samples on standing (8). Akcay \& Rose showed that glyoxylic acid added to blood samples is converted to oxalic acid immediately by erythrocytes (8). Rehmert and coworkers demonstrated the in-vitro synthesis of oxalic acid in plasma of normals. The formation of oxalic acid could be prevented by addition of enzyme inhibitors (3). In addition to glyoxylic acid, other precursors, like glycolic acid, ascorbic acid or glycine, could contribute to in vitro synthesis of oxalic acid (10). In uraemia, the accumulation of these compounds, resulting in elevated plasma levels, can be expected or has even been proved. Therefore an increased in vitro formation of oxalic acid from precursors might be expected in uraemia. Our results, however, demonstrate that the in vitro conversion of these precursors could make only a negligibly small contribution to the elevated plasma oxalic acid concentrations in uraemic patients. In fact, such a conversion cannot be demonstrated by the method used. It can therefore be assumed that the increased plasma oxalic acid concentrations measured in uraemia genuinely reflect the accumulation of oxalic acid in renal failure.

\section{References}

1. Zarembsky, P. M. \& Hodgkinson, A. (1966) Nature 212, 511-512.

2. Balcke, P., Schmidt, P., Zazgornik, J., Kopsa, H. \& Deutsch, E. (1980) N. Engl. J. Med. 303, 944.

3. Rehmert, U., Wicher, K., Ruge, W. \& Bahlmann, J. (1983) Lab. Med. 7, 29-32.

4. Krugers Dagneaux, P. G. L. C., Klein Elhorst, J. T. \& Olthuis, F. M. F. G. (1976) Clin. Chim. Acta 71, 319-325.

5. Hatch, M., Bourke, E. \& Costello, J. (1977) Clin. Chem. 23, 76-78.

6. Hodgkinson, A. \& Wilkinson, R. (1974) Clin. Sci. Mol. Med. 46, 61-73.

7. Kohlbecker, G. \& Butz, M. (1981) J. Clin. Chem. Clin. Biochem. 19, 1103-1106.

8. Akcay, T. \& Rose, G. A. (1980) Clin. Chim. Acta 101, 305311.

9. Schmidt, P., Endler, A. T., Kopsa, H., Zazgornik, J. \& Balcke, P. (1980) 5. Donausymposion für Nephrologie. Linz.

10. Schröder, R. (1980) Dtsch. Med. Wochenschr. 105. 9971001.
Dr. P. Balcke

I. Medizinische Universitätsklinik Wien

Lazarettgasse 14

A-1090 Wien 
